\title{
Membran Biyoreaktör ve Dinamik Membran Biyoreaktör Performansının Aynı Koşullarda Kıyaslanması
}

\author{
Mehmet Akif Veral ${ }^{1,2}$, Abdullah Kızılet ${ }^{3}$, Özer Çınar, \\ ${ }^{1}$ Istanbul Sabahattin Zaim University, Halal Food and R\&D Center, Halkalı Campus, 34303, Küçükçekmece/ Istanbul, Turkey (ORCID: 0000-0002-5933-1598) \\ ${ }^{2}$ Yıldız Technical University, Faculty of Chemical and Metallurgical Engineering, Department of Bioengineering, 34210, Esenler/ Istanbul, Turkey (ORCID: 0000- \\ 0002-5933-1598) \\ ${ }^{3}$ Kahramanmaras Sutcu Imam University, Institute of Science and Technology, Department of Bioengineering and Sciences, 46100, Kahramanmaras, Turkey (ORCID: \\ 0000-0002-5933-1598) \\ ${ }^{4}$ Y1ldiz Technical University, Faculty of Civil Engineering, Department of Environmental Engineering, 34210, Esenler/ Istanbul, Turkey (ORCID: 0000-0002-3023- \\ 0734)
}

(İlk Geliş Tarihi 12 Eylül 2019 ve Kabul Tarihi 7 Şubat 2020)

(DOI: 10.31590 /ejosat.619539)

ATIF/REFERENCE: Veral, M. A., Kızılet, A. \& Çınar, Ö. (2020). Membran Biyoreaktör ve Dinamik Membran Biyoreaktör Performansının Aynı Koşullarda Kıyaslanması. Avrupa Bilim ve Teknoloji Dergisi, (18), 30-41.

\section{$\ddot{\mathrm{O} z}$}

Bu çalışma, sentetik atık su arıtımı için aerobik membran biyoreaktörde (AeMBR), 0,45 $\mu \mathrm{m}$ ve dokuma olmayan membran olmak üzere iki farklı membran modülünün karşılaştırmalı değerlendirilmesini amaçlamaktadır. Her iki membran malzemesinin filttrasyon performansları aynı operasyonel şartlar altında karşılaştırılmıştır. Filtreleme işlemi boyunca, 0,45 $\mu$ m ve dokuma olmayan membran olmak üzere sırasıyla \%99 ve \% 95 kimyasal oksijen ihtiyacı (KOİ) giderim verimleri elde edilmiştr. AeMBR, 10 LMH'de başarıyla işletilmiş ve 30 gün boyunca hiçbir şekilde kimyasal yıkama uygulanmamıştır. Reaktör, 15 LMH akıya kadar mükemmel bir şekilde işletilmi ve sonra 20 LMH'de işletime devam edilmiştir. $0.45 \mu \mathrm{m}$ membranın bulanıklık ve trans-membran basıncı değerleri, dokuma olmayan membrana nispeten başlarda genellikle yüksek sonuçlar vermiştir. Membranlar üzerinde oluşan kek tabakasının karakteristik özelliklerini belirlemek üzere kapiler emme süresi (CST), çözünür mikrobiyal ürün (SMP), hücre dış1 polimerik bileşenler (EPS), süzülmeye karşı spesifik direnç (SRF), fourier dönüşümlü kızılötesi spektroskopisi (FT-IR) ve denatüre gradyan jel elektroforezi (DGGE) aanalizleri yapılmıştır. 16S rDNA bölgesi, hava/ortam sıcaklığı değişikliği açısından önemli sonuç göstermiştir. Her iki membran modülü için, sırasıyla $\mathrm{NaOCl}$ ve sülfürik asit ile yapılan kimyasal temizleme istihdamı, neredeyse tamamen tıkanmaları ortadan kaldırmış ve kimyasal olarak yıkanmış membranların, yeni membranlarınkine yakın basınç gösterdiği bulunmuştur.

Anahtar Kelimeler: Dinamik membran biyoreaktör, dokuma olmayan, $0.45 \mu \mathrm{m}$ membrane, biyolojik arıtım, KOİ giderimi, PES

\section{Membrane Bioreactor and Dynamic Membrane Bioreactor Performance Comparison under the Same Conditions}

\begin{abstract}
This study aims comparative evaluation of two different membrane modules, $0.45 \mu \mathrm{m}$ and non-woven dynamic membrane, in AeMBR for synthetic wastewater treatment. Filtration performances of both membrane materials were compared under same operational conditions. Throughout the filtration process, 99\% and 95\% chemical oxygen demand (COD) removal efficiencies were achieved relying upon $0.45 \mu \mathrm{m}$ and non-woven dynamic membrane, respectively. AeMBR was successfully operated at $10 \mathrm{LMH}$ and no chemical cleaning was employed for 30 days. It was perfectly operated up to $15 \mathrm{LMH}$ and then $20 \mathrm{LMH}$. The turbidity and trans-membrane pressure (TMP) of $0.45 \mu \mathrm{m}$ was usually higher at the begging compared with the dynamic membrane despite membrane clogging rates were comparable. Capillary suction time (CST), soluble microbial product (SMP), extracellular polymeric substances (EPS), specific resistance to filterability (SRF), attenuated total reflectance fourier transformed-infrared spectroscopy (ATR FT-IR) and denaturing
\end{abstract}

\footnotetext{
* Sorumlu Yazar: Y1ldiz Technical University, Faculty of Civil Engineering, Department of Environmental Engineering, 34210, Esenler/ Istanbul,

Turkey, ORCID: 0000-0002-3023-0734,ocinar@yildiz.edu.tr
} 
gradient gel electrophoresis (DGGE) analyzes were performed to understand the characterization of the cake deposited on membranes. $16 \mathrm{~S}$ rDNA region shown significant result in terms of air/ambient temperature change. For both membrane modules, offline chemical cleaning employment with $\mathrm{NaOCl}$ and sulfuric acid, respectively, almost completely eliminated foulants and it was found that chemically washed membranes showed pressure close to that of the new membrane.

Keywords: Dynamic membrane bioreactor, non-woven, $0.45 \mu \mathrm{m}$ membrane, biological treatment, COD removal, PES

\section{Introduction}

Membrane bioreactor (MBR) systems are accepted as one of the most critical industries in terms of wastewater treatment operations and environmental health issues. The amount of wastewater utilized for treatment operation is increasing parallel to the world population. In this context, there has been growing rate of interest to the MBR systems to reduce the water pollution caused by not only mankind but also the industries. In the field of MBR technology, different types of membranes and support materials are employed for treatment processes for reuse of wastewater and resource convalesce. It is known that if the wastewater is discharged as a result of inadequate treatment, there are various problems show up in water resources.

Besides, being an excellent member in solid/liquid separation processes, it has also significant advantages such as small footprint and good permeate quality (Reid et al. 2006). In spite of its supremacy, there are some primary deficiencies like high operational cost, high membrane cost, low flux and getting membrane fouling under control. Thereby, dynamic membrane formation on the surface of the membrane is an encouraging approach in terms of generating appropriate solution for wastewater treatment operations. (Kiso et al. 2010; Ma et al. 2013). Dynamic membrane (DM), also called as secondary membrane, is generated on the surface of the support material which may be sometimes membrane or different types of textile materials such as mesh, non-woven fabric or filter cloth alternatively to the microfiltration (MF) or ultrafiltration (UF) membranes. When the wastewater is filtered, non-filterable colloidal constituents are confined over cake layer that hinders the fouling problem of membrane material; (Jeison and van Lier 2006; Sun et al. 2016). DM technology, as well as being easy and wide spread, is open for different types of operational modifications.

It is critical to indicate that, membrane itself cannot be necessarily required for the filtration processes, when the dynamic membrane formed over the surface of the support layer and act as a barrier to procure colloidal particle rejection. When the cake layer loses its permeability due to bacterial or colloidal intensity, membrane is exposed to the cleaning process that shouldn't be continuously implemented (S. Lee et al. 2011).

In several experiments, DM technology has been employed for treatment of municipal wastewater in anaerobic membrane bioreactor (AnMBR) (H. Chu et al. 2014; Ersahin et al. 2014; Y. Chen and Ho 2016) and operational outcomes from the experiments represented that $98 \%$ permeate quality has been achieved in the process. After continuous treatment throughout the operation, membrane can come across intensive fouling problem and so that the DM tier can be supplied by different layer of residue.

In this article, two different membrane types, $0.45 \mu \mathrm{m}$ and non-woven, have been employed for the treatment process. Membrane performances cake characteristics were compared in each other in terms of turbidity, ATR FT-IR, SMP/EPS, SRF, SF, DGGE, CST and TMP.

\section{Material and Method}

\subsection{Membrane bioreactor and experimental setup}

Two different membrane modules were developed and one lab scale AeMBR tank was designed. It was made of plexiglass at dimensions of $8 \times 14 \times 38 \mathrm{~cm}$ operated in total volume of $3 \mathrm{~L}$ and active volume of $2.5 \mathrm{~L}$. Reactor was equipped with a water level sensor and an aeration device at the bottom. Inside of the tank, two different membrane types, non-woven flat-sheet polyethersulfone (PES) and $0.45 \mu \mathrm{m}$ membranes were used for the operation and double-sided support layer was used for the membrane stableness. Each membrane module, made of $12 \times 12 \mathrm{~cm}$ plexiglass, had volume of $217 \mathrm{ml}$ and the active surface area was adjusted to $7.5 \times 7.5 \mathrm{~cm} 2($ Fig. $1)$.

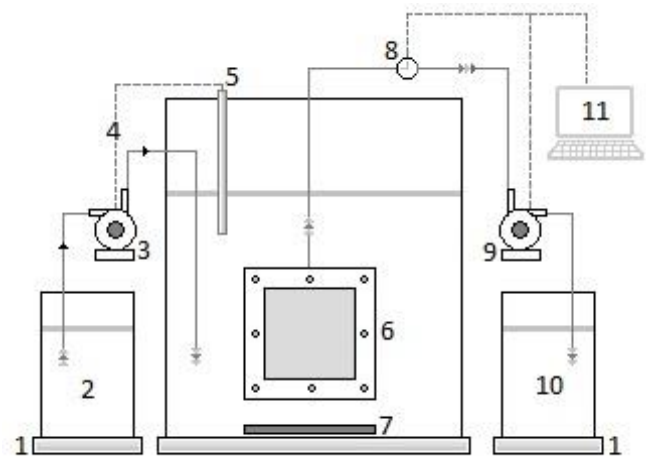

Fig. 1. Schematic of MBR system: 1. Balance, 2. Fee tank, 3. Feed pump, 4. Feed controller, 5. Level sensor, 6. Membrane module, 7. Air blower, 8. Digital manometer, 9. Suction Pump, 10. Permeate tank, 11. Data recording/reading. 


\subsection{Membrane bioreactor and experimental setup Membrane cleaning and fouling control}

AeMBR system was fed with synthetic wastewater (Cinar et al. 2008) including $500 \mathrm{mg} / \mathrm{L}$ COD glucose and essential inorganic nutrients which are critical for microbial growth. At the outset of the operation, suspended solid (SS) concentration was stabilized at 4 $\mathrm{g} / \mathrm{L}$. Inoculated sludge was adopted from the last sedimentation tank of a full-scale wastewater treatment plant. MBR system was operated at room temperature with a level censor and amount of the feed provided from tank.

Performance measurements of AeMBR system were considered with different flux parameters. The reactor was operated with infinite SRT for 137 days and therefore no sludge withdrawal was performed. System was initially operated at $11.11 \mathrm{LMH}$ flux (10 LMH net flux). SADm value and flow rate was $1 \mathrm{~nm} 3($ air $) / \mathrm{m} 2 . \mathrm{hr}$ and $2.08 \mathrm{ml} / \mathrm{min}$, respectively. Due to membrane fouling which is one of the most critical problem encountered throughout the filtration, the process was maintained discontinuously ( 4.5 min suction and 0.5 min relaxation) to manage reversible fouling could be reduced by physically washing the membrane (Arhin et al. 2016) or relaxation (J. Wu et al. 2008).

Operational performance of the MBR system was examined with different flux values during 30 days of stable working and additional 15 days of analysis for each individual periods. In the first period of the operation net flux maintained at $10 \mathrm{LMH}$ and membrane and sludge-related data were recorded. In the second and third period of the operation, net flux increased to 15 and $20 \mathrm{LMH}$, respectively. Each individual period allowed comparison of collected data depending on the flux change.

\subsection{Membrane cleaning and fouling control}

Both membrane modules were operated at a constant flow and periodically these flow values were modified to examine membrane performance. The TMP values were recorded online for a certain period during the examination. Within the first 45 days of the study, the membranes surface was peeled off by applying physical cleaning with a pressure of $0.30-0.35$ bars, at $10 \mathrm{LMH}$ flux, followed by chemical cleaning. After day 45, membrane blockage began to occur more frequently with increased flux and with the pressure reaching 0.35 bars, first physical cleaning employed with a soft scouring pad under tap water then chemical cleaning employed. Within the first 45 days, chemical cleaning was applied only once, except for physical washing only. Physical cleaning ensures that the permeability of the membrane surface was maintained for a while. In this and following sections of the work, chemical cleaning was employed as physical cleaning (peeling off the cake layer on the surface of the membrane) and entreating the membrane to $\mathrm{NaOCl}(300 \mathrm{mg} / \mathrm{L})$. Then membrane was gently washed with tap water and soaked into the sulfuric acid solution $(\mathrm{pH}=2)$ for an hour.

\subsection{Membrane fouling characterization}

Flux is the amount of water passing along the unit surface area of membrane per unit of time (J) (Judd 2010). It is known that the membranes are frequently blocked with increasing flux, which in turn leads to an increase in TMP values (Mohammadi et al. 2003; Hernandez Rojas et al. 2005). At the beginning of the operation, the flux was set to $10 \mathrm{LMH}$ then performance of the operation was tested with $15 \mathrm{LMH}$ and $20 \mathrm{LMH}$ respectively.

TMP data, recorded with digital manometer, were used for characterization of the membrane fouling. Membrane filtration resistance was calculated with Darcy Equation to evaluate the degree of membrane fouling in AeMBR (Z. Wu et al. 2007).

$$
\mathrm{R}=\mathrm{TMP} /(\mu \mathrm{J})
$$

where $\mathrm{J}$ is the flux as $\mathrm{m} 3 /(\mathrm{m} 2 . \mathrm{s})$, TMP is the trans membrane pressure as $\mathrm{Pa}, \mu$ is the permeate viscosity as Pa.s, and $\mathrm{R}$ is the membrane filtration resistance as $1 / \mathrm{m}$. Throughout the intermittent operation of MBR system, 5 min. of filtration and 0.5 min. of relaxation employed. With the stop of the filtration process, aeration created an effective shear force over the membrane surface. Thus, it was assumed that there was no reversible fouling during its relaxation period.

During the MBR operation, the membrane was physically and chemically washed many times and it was found that after the washing process the pressure gradually starts from a certain level (irreversible fouling). Rf was called irreversible fouling (unrecoverable by physical interference). Even though chemical cleaning compensated a large part of the fouling, some of the foulants might not be eliminated (cannot be recovered) (Wang et al. 2014) which critically effects the performance of the membrane over the long run.

\subsection{Microbiological analysis}

Samples that were taken from first and last operational period as a mixed liquor were used for DNA extraction by using PowerSoil DNA isolation kit (MO BIO Laboratories Inc.) according to the extraction manual and stored at $-20^{\circ} \mathrm{C}$. PCR operations were performed with the universal 16S primers 27F, Bact-1492R, 357F-GC, R518 and PRB-357F. Primers and PCR amplification procedures of the microbial community were previously described (S.-Y. Lee et al. 2004; Liu et al. 2010). DGGE operation was performed with D-Code Universal Mutation Detection System (Bio-Rad, Netherlands).

Thermal Cycler using the PCR method amplified the 16S rDNA genes of the extracted DNA mixtures. Microbial species diversity was detected by DGGE and DNA sequence analysis (Özkaya and Demir 2011). Therefore, PCR1 and PCR2 procedures were edit according to the procedure made my Lee et al. (S.-Y. Lee et al. 2004). 


\subsection{Analytical Methods}

Samples were picked up from influent, mixed liquor and permeate of the MBR system. Analyzes of COD (from permeate), CST, SRF/SF, SEM, FT-IR and DGGE samples were directly carried out without filtration. TMP, $\mathrm{pH}$ and ORP values were daily measured. COD was measured according to the Standard Methods [21]. Mixed liquor suspended solid concentration in the bioreactor was measured according to Standard Methods $2540 \mathrm{D} / \mathrm{E}$ [22]. For SMP/EPS analysis, mixed liquor was centrifuged at $4000 \mathrm{rpm}$ for $10 \mathrm{~min}$ and supernatant was subjected to filtration with membrane pore size of $0.45 \mu \mathrm{m}$. SMP measurements were carried out from the supernatant in terms of protein and carbohydrates concentrations (Bradford and Dubois Methods). The remaining pellet portion from the centrifuge was washed twice and incubated in salty water $(0.5 \% \mathrm{NaCl})$ for EPS analysis. The mixed liquor was incubated with heat $\left(80^{\circ} \mathrm{C}, 1 \mathrm{~h}\right)$ and then centrifuged once again. The supernatant was subjected to filtration by $0.45 \mu \mathrm{m}$ pore sized filter paper and permeate EPS concentration was revised from previous researches [23]. For CST analysis, $2 \mathrm{ml}$ of mixed liquor placed on a Whatman \#17 filter paper to measure viscosity for each experimental phase. ATR-FTIR device (Thermo iS10) was used to characterize the sludge and to understand its chemical bond structure. Pellet of $2 \mathrm{ml}$ centrifuged mixed liquor and membrane cake layers were subjected to exsiccation $\left(60{ }^{\circ} \mathrm{C}, 24 \mathrm{~h}\right)$. Dried samples were grinded fairly in mortar and placed to the device. SF and SRF work was done to measure $100 \mathrm{ml}$ mixed liquor MBR sludge filterability and filtration resistance. Depending on the dead-end device (Sterlitech, P/N HP4750), the centrifuged (SF) and non-centrifuged samples (SRF) were filtered with pure nitrogen gas pressure with a stirrer and $0.45 \mu \mathrm{m}$ membrane (Whatman, WHA7404004). SRF measurements were performed every 1 min on 1 hour measurement and SF measurements on every 1 sec on a minute. Filtered liquid was weighed online and the results were recorded. For SEM analysis (Zeiss EVO® LS 10), small dried $\left(60{ }^{\circ} \mathrm{C}, 24 \mathrm{~h}\right)$ sections of the membranes were performed in Gaziantep University-SEM Laboratory.

\section{Results and Discussion}

\subsection{Membrane bioreactor performace}

MBR system was operated through 137 days. Each period lasted for 45 days and the reactor was operated at steady state for 30 days. Nearly in a week, COD concentration in the permeate reached steady values. After 30 days of steady state operation, 15 days of data collection was carried out. Figures were presented with 15-day periods. In the first period (10 LMH), $0.45 \mu \mathrm{m}$ and non-woven dynamic membrane average permeate COD concentrations were found $3.8 \mathrm{mg} / \mathrm{L}$ and $25 \mathrm{mg} / \mathrm{L}$, respectively, like wise, $0.45 \mu \mathrm{m}$ and non-woven dynamic membrane average COD removal efficiencies were $99.47 \%$ and $97.02 \%$, respectively (Fig. 2).

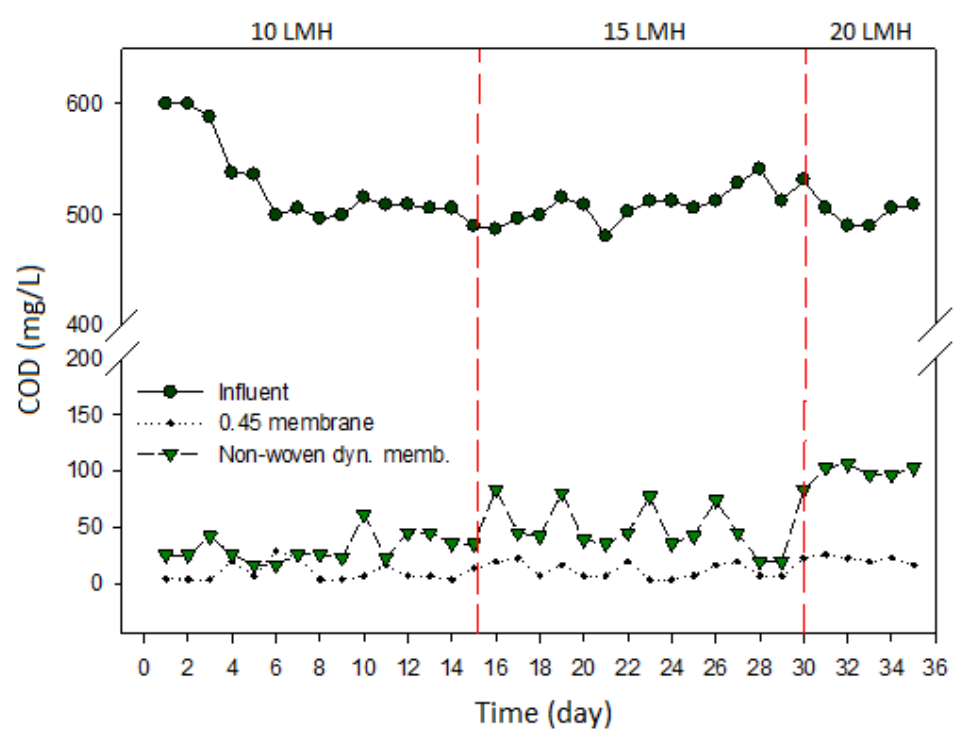

Fig. 2. COD removal performance of MBR.

In the second period (15 LMH), Average COD concentrations of the $0.45 \mu \mathrm{m}$ and non-woven dynamic membrane permeates were 11.9 (96.05\% efficiency) and $50.87 \mathrm{mg} / \mathrm{L}$ (82.89\% efficiency), respectively. In addition, $0.45 \mu \mathrm{m}$ and non-woven dynamic membrane performances also showed efficient treatment in terms of COD removal for the second period of the experiment. During the first phases of 30 days of steady state operation, low yield was obtained because no cake/gel layer was formed on the dynamic membrane. It was seen that a dense portion of synthetically supplied COD was removed in the proceeding phase and it exhibited effective filtration to reject particulate matter. Similar investigations were made in other operations (Fan and Huang 2002; L. Chu and Li 2006).

In the third period (20 LMH), with increasing flux, COD filtration quality of the dynamic membrane permeate decreased, while the permeate parameters of the $0.45 \mu \mathrm{m}$ membrane was not changed much. This is due to the fact that there was no active cake layer on the membrane surface and immature cake layer cannot perform effective filtration. $0.45 \mu \mathrm{m}$ and non-woven dynamic membrane average permeate COD concentrations were found to be 21.12 (95\% yield) and $100.87 \mathrm{mg} / \mathrm{L}$ ( $79 \%$ yield), respectively.

However, permeate COD concentrations were lower than the COD concentration of filtered reactor mixed liquor. The reason is that both the SMPs of the cake and gel layer on the membrane are biodegraded and the effective pore diameter on the membrane decreases as the cake layer develops. Similar finding was also reported in the literature (Jiang et al. 2008). 


\subsection{SMP and EPS concentrations in MBR Flux, TMP and Turbidity changes}

MLSS measurements were performed once a week for each period. The initial MLSS concentration was set at approximately 4000 $\mathrm{mg} / \mathrm{L}$. Throughout the 135-day operational period, MLSS concentration increased in very small quantities and the final concentration was measured as $4177 \mathrm{mg} / \mathrm{L}$. Theoretically, no sludge was discharged from the reactor, meaning the reactor was operated at infinite SRT. Daily and weekly experimental work and the amount of sludge taken from the reactor as a result of the repetition of these studies compensated the SRT period of this study. It was reported in the literature that high-order biomass and high COD removal efficiency were obtained from MBR systems (Fu et al. 2009; Yurtsever et al. 2017) operated with infinite SRT and during this time, the effect of membrane fouling was evaluated.

In the literature, there are many studies on membrane fouling originating from SMP and EPS (Drews et al. 2006; Trussell et al. 2006; Jeong et al. 2007; Jiang et al. 2008; Meng et al. 2009). These parameters were analyzed according to periods were given in Table 1 and total SMP and EPS concentrations were represented in Fig. 3. In SMPs, there are many micro molecules such as humic acid, polysaccharides, protein complexes, and amino acids. It is mentioned in the literature that these molecules seriously affect the sludge kinetic activity (Azami et al. 2012). Three different SMP and EPS samples have been studied in our work. The average SMP concentrations of $0.45 \mu \mathrm{m}$ and non-woven dynamic membrane permeates were found as $21.9626 \mathrm{mg} / \mathrm{L}$ and $31.5488 \mathrm{mg} / \mathrm{L}$, respectively. However, average SMP concentration of centrifuged MBR sludge supernatant was found as $39.348 \mathrm{mg} / \mathrm{L}$.

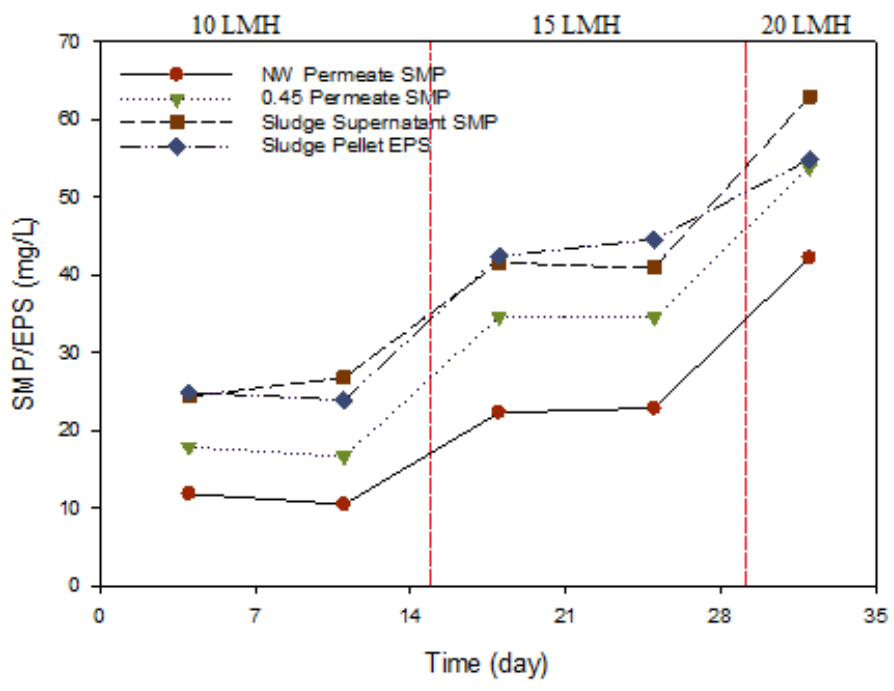

Fig. 3. SMP and EPS concentrations of the MBR operation.

It is important to indicate that SMP production in the reactor was found almost 3\% and 4\% of the biodegraded COD was converted into the SMP. Normalized SMP production in AeMBR systems (fed with glucose) was found as $3.1 \% \pm 0.4 \%$ in the literature (Barker and Stuckey 1999) and it was found in previous studies that the SMP value decreases with increasing SRT value (Katsuki et al. 2009). Permeate SMP value were found in the range of 4-5\% (Kiser et al. 2010), which was a good agreement with our experimental findings, with high SRT.

The data obtained from the EPS analyzes are represented in Fig. 3. Throughout the reactor operation, it was seen that there are regular but small increases in EPS values, similar to the gradually increasing MLSS concentrations. Average centrifuged MBR sludge pellet EPS concentration was found as $38,1654 \mathrm{mg} / \mathrm{L}$. One of the important inference might be the thickness of the cake/gel layer formed on the membrane surface and an effective filtration due to this thickening.

In bioreactor, EPS concentration increased consistently. This increase will cause the membrane clogged and the membrane resistance to increase rapidly in the progressive stages. It was reported in the literature that increased membrane pressure was observed due to wastewater characterization (Chae et al. 2006).

\subsection{Flux, TMP and Turbidity changes}

AeMBR system was operated throughout 135 days. During the operation, TMP values were recorded intermittently with a daily period. Flux and corresponding changes in TMP were shown in Fig. 4 . In the system, the TMP reached a high value ( 0.3 bars) shortly after the start of the operation. The consequence for the TMP value being so unstable might be related with two possible reasons. First one is the acclimation of the sludge which changes the microbial community. Second one is the only offline physical cleaning application. Even though the TMP was fell down, the foulants were not efficiently removed. When the TPM reached high values membranes were subjected to chemical cleaning right after the cake/gel layer peeled off. With a steady increase in TMP value (0-0.3 bars) non-woven 
and $0.45 \mu \mathrm{m}$ membranes were subjected to chemical cleaning at day-10 and day-12 respectively. It was even efficient to clean the membrane with low concentration of $\mathrm{NaOCl}(300 \mathrm{mg} / \mathrm{L}$ ) to remove fouling layer (Wang et al. 2014).

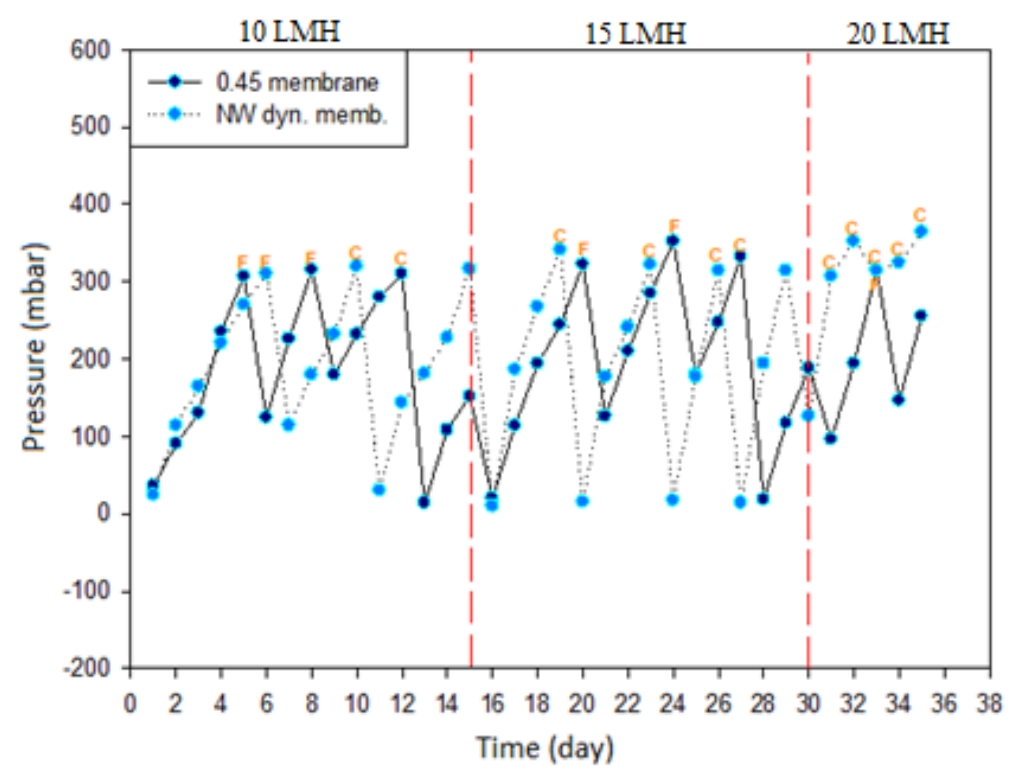

Fig. 4. TMP changes throughout the operational periods.

It should be deducted that the cause of the cleaning process was caused by the acclimation of the sludge. After cleaning, the pressure was close to zero for the dynamic membrane and $14 \mathrm{mbar}$ for the $0.45 \mu \mathrm{m}$ membrane. It was estimated that the sludge from the final settling tank was likely to contain biodegradable organic colloidal particles (increasing the pressure). The biodegradation of these particles may fall the pressure. During this time period, the average pressures were 124 and 194 mbars for $0.45 \mu \mathrm{m}$ and non-woven dynamic membrane, respectively.

After Day-15 the flux was increased to $15 \mathrm{LMH}$. At this stage, the TMP value was above 0.3 bar for a very short time for both membranes (Fig. 4). The dynamic membrane was subjected to chemical cleaning (day 19, 23 and 26) while physical cleaning was sufficient for 0.45 $\mu \mathrm{m}$ membrane for a while, and was subjected to chemical washing at day 27. While physical washing was sufficient for $0.45 \mu \mathrm{m}$ membrane for some time, it was exposed to chemical cleaning on day-27. In the last period of the operation the flux was increased to $20 \mathrm{LMH}$. At this stage, the dynamic membrane was seriously clogged and subject to daily chemical washing.

On the other hand, the pressure of $0.45 \mu \mathrm{m}$ membrane increased over 0.3 bar within 3 days and exposed to physical cleaning with a sponge under tap water that was not influential for the fouling control (Fig. 4).

Daily turbidity values measured from the permeates were shown in Fig. 5. Turbidity is the loss of transparency of water and the presence of invisible solid matter in the particulate level (Judd 2010). The increase/decrease in turbidity was directly related to the filtration performances and the physical/chemical cleaning operations with increased pressure. In the first period of the MBR operation, average turbidity values of $0.45 \mu \mathrm{m}$ and non-woven dynamic membranes were 0.2 and $3.3 \mathrm{NTU}$, respectively. Although, at the beginning of the first period, the dynamic membrane permeate turbidity values showed partial stability, these values rapidly fluctuated in the following periods. On the 10th (non-woven membrane) and 12th $(0.45 \mu \mathrm{m})$ days, membranes were exposed to chemical cleaning due to high TMP variations and turbidity values were found to be $7.2 \mathrm{NTU}$ and $0.2 \mathrm{NTU}$, respectively. In the second period (10 to $15 \mathrm{LMH}$ ), while the $0.45 \mu \mathrm{m}$ membrane turbidity values were steady, dynamic membrane turbidity values frequently changed between $2-5 \mathrm{NTU}$. In the last period, with increasing flux, TMP reached around 0.4 bars and it almost stopped the filtration for dynamic membrane.

The daily increase in TMP, physical and chemical cleaning of the membrane, and increased turbidity values resulted in reduced efficiency. Although the membrane surface was quickly coated with bacteria, this was not a very healthy operation for MBR operation. It was reported that the microbial community in the reactor flocked on the membrane in very short time and the resulting turbidity values decreased (Ren et al. 2010) and with the formation of dynamic membranes, the turbidity values decreased by $99 \%$ (Ersahin et al. 2014). The low turbidity values of the $0.45 \mu \mathrm{m}$ membrane and long-term high-flux operation might be a problem for average life-span of the membrane. 


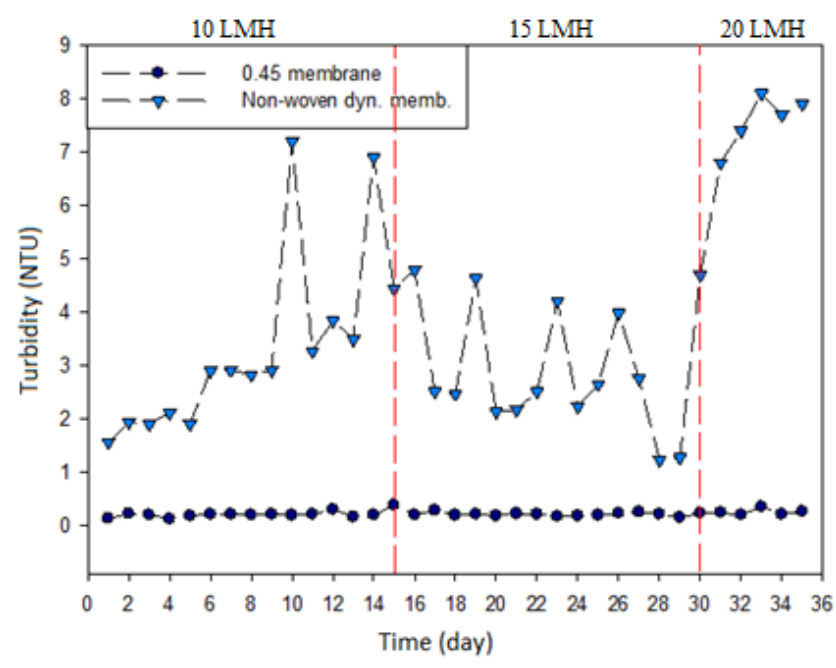

Fig. 5. Turbidity variations throughout the MBR operation.

\subsection{Sludge fluidity, filterability and specific resistance to filtration results}

CST was used to identify the sludge filterability characteristics and it measures the time of water drop from the sludge moved $1 \mathrm{~cm}$ path in a porous membrane (Judd 2010). For the analysis performed for each operational period, the initial CST value was measured as 54.9 sec. During the time period between period I and period II, the concentration of SMP, EPS and MLSS in the reactor increased. After the flux raised to $15 \mathrm{LMH}$, CST result of $57.2 \mathrm{sec}$. was obtained. Viscosity of the sludge directly affected by the increase in sludge concentration (Germain et al. 2005). In the final period of the experiment, CST value was found as $64.4 \mathrm{sec}$. After each study, it was determined that CST value increased in parallel with MLSS, SMP and EPS values. Wang et al. reported that CST, EPS, MLSS, carbohydrates and proteins had serious effects on membrane fouling which effects the filtration performance considerably (Wang et al. 2006). In another study, it was reported that high CST values would result in low filtration (G. W. Chen et al. 1996) which was a good agreement with our findings.

One of the most important factors illuminating the membrane fouling is SF and SRF values. The increase and decrease of these values also represent in Fig. 6. While SF samples were prepared with $10 \mathrm{~min}$. centrifugation at $4000 \mathrm{rpm}$ and poured into the dead-end chamber with a magnetic stirrer, SRF samples were prepared without centrifugation and magnetic stirrer. The sample in the dead-end device was weighed by the pressure $\left(0.5\right.$ bars) created by the $\mathrm{N}_{2}$ gas, filtered through the filter at the bottom of the device, and the results were recorded simultaneously. The initial SF and SRF results were found as $100 \mathrm{gr}$ and $57 \mathrm{gr}$ of permeate, respectively. As a result of the SF and SRF analyzes carried out in the second period of the study, the time elapsed during the filtration increased relatively to the previous work and the results in the second period were found as $96.6 \mathrm{gr}$ and $48 \mathrm{gr}$, respectively. In the last phase of the experiment, SF and SRF results were recorded as $91.2 \mathrm{gr}$ and $37.3 \mathrm{gr}$, respectively. As a result of periodic studies, SF and SRF values were found to be relatively lower than the previous study. This reduction was associated with an increase in the SMP, EPS (Fig. 3) and MLSS concentration of the reactor sludge which were parallel in accordance with the earlier studies (Rosenberger and Kraume 2003; Galil and Jacob 2009; Yu et al. 2009). The reduction in the amount of filtered sample was also indicative of changes in the sludge matrix with the change of the sludge characteristics.

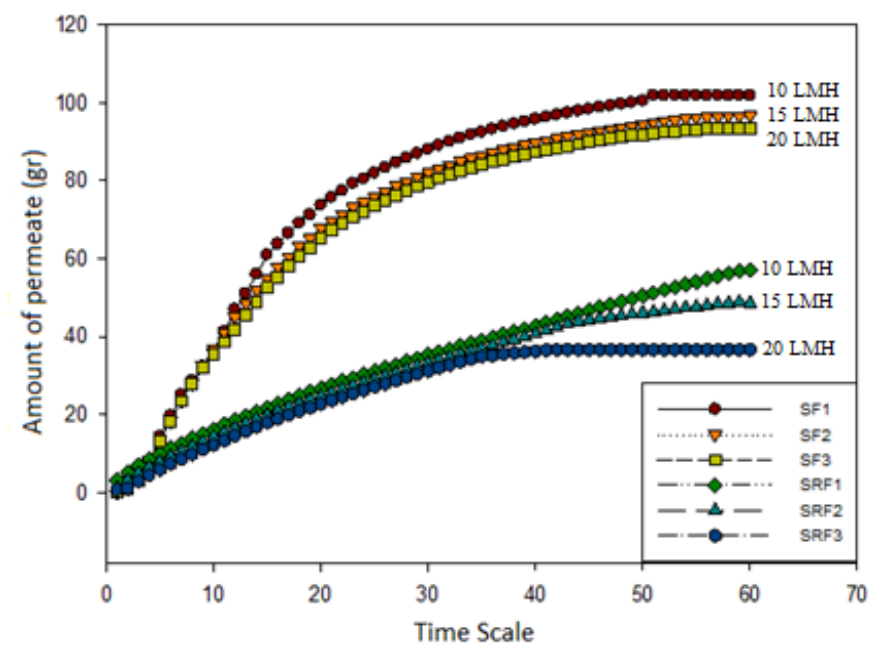

Fig. 6. SF and SRF Filtration results of the MBR mixed liquor. 


\subsection{Membrane Analysis}

\subsubsection{ATR FT-IR results of the virgin and used membrane}

ATR FT-IR analysis was performed not only to analyze the fouling of membranes due to SMP, EPS and MLSS concentrations but also to clarify which chemical bonds are formed with the adherence of the components causing the clogging to the membrane surface. At the end of last periods, small cross-sections of $0.45 \mu \mathrm{m}$ and non-woven dynamic membranes were stoved (60 C, $24 \mathrm{hr}$.) and cake layer was used to measure the thickness of the gel. Comparison of the cake layer formed over $0.45 \mu \mathrm{m}$ and non-woven dynamic membrane surface were examined. The peaks obtained in the FTIR analysis were shown in Fig. 7 for $0.45 \mu \mathrm{m}$ and non-woven dynamic membrane, respectively.

It was found that the peak at 1027 and $1042 \mathrm{~cm}^{-1}(\mathrm{C}-\mathrm{O})$ represented polysaccharide property (K. Kimura et al. 2005) and peak at 1634 $\mathrm{cm}^{-1}$ was represented as CO stretched proteins (amid I groups) (Croue et al. 2003). Similar results were also found by Kim et al. regarding upon $1634 \mathrm{~cm}^{-1}$ (Kim and Jang 2006). The peak $1722 \mathrm{~cm}^{-1}$ for non-woven dynamic membrane associated with carboxylic acids humic substances (Jarusutthirak 2003).

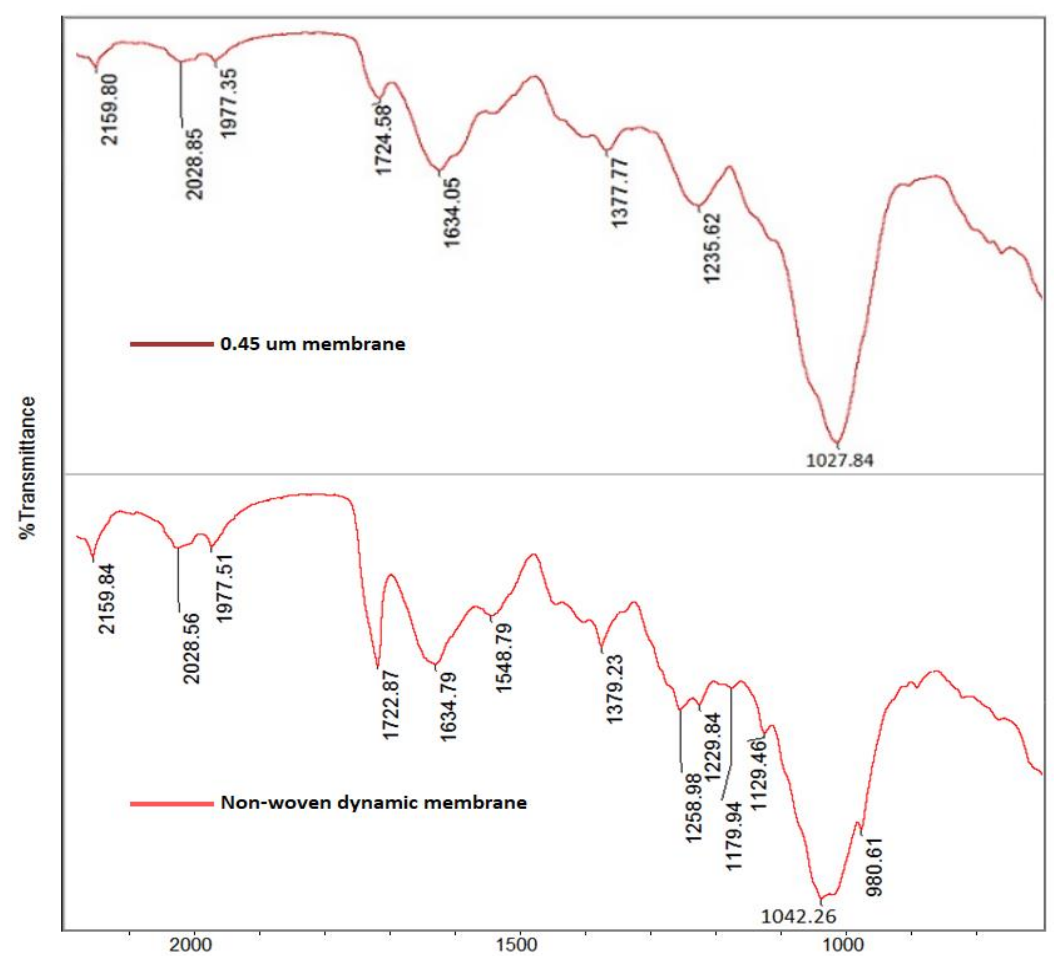

Fig. 7. $0.45 \mu \mathrm{m}$ and non-woven dynamic membrane ATR-FTIR results.

\subsubsection{Inorganic cake constituents and optical scanning}

Scanned cross-section of fouled $0.45 \mu \mathrm{m}$ and non-woven dynamic membranes SEM images were represented at Fig. 8. Thickness of the cake layers in the cross-sectional surface of the $0.45 \mu \mathrm{m}$ and non-woven dynamic membranes were found around $121 \mu \mathrm{m}$ and 317 $\mu \mathrm{m}$, respectively. The cake layer over the surface of non-woven dynamic membrane was found thicker, less porous and rigid than 0.45 $\mu \mathrm{m}$ membrane. Due to large pore size of the non-woven dynamic membrane, it appeared coarse due to intensive organic foulants accumulation (An et al. 2009).

Fouling compositions of the foulants and concentrations, such as $\mathrm{Na}, \mathrm{Mg}, \mathrm{Al}, \mathrm{Si}, \mathrm{S}, \mathrm{Cl}, \mathrm{Ca}, \mathrm{Ni}, \mathrm{Cr}$ and $\mathrm{Zn}$ in the cake layer, were measured with SEM-EDS analysis (Fig. 9). The SEM-EDS analysis was performed for both membrane types and the ratios of organic and inorganic chemicals detected on the cake were determined more intensively on the dynamic membrane. Existence of $\mathrm{S}$ might occurred due to formation of elemental S. Even though, high oxygen concentration may caused sulfide to sulfite as a chemical reaction, small percentage of the sulfide might be oxidized to elemental S. Therefore, the S concentration was much higher in non-woven dynamic membrane. The Al, $\mathrm{Ca}$ and $\mathrm{Si}$ concentrations in the cake layer of $0.45 \mu \mathrm{m}$ and non-woven dynamic membrane were found around 0.2 , 0.8 and $1.5 \mathrm{mg} / \mathrm{m}^{2}$ and $0.3,1.4$, and $1.1 \mathrm{mg} / \mathrm{m}^{2}$, respectively. $\mathrm{C}$ and $\mathrm{O}$ observed in the cake layer developed on the membranes were thought to originate from the bacterial mass (Fig. 9). 

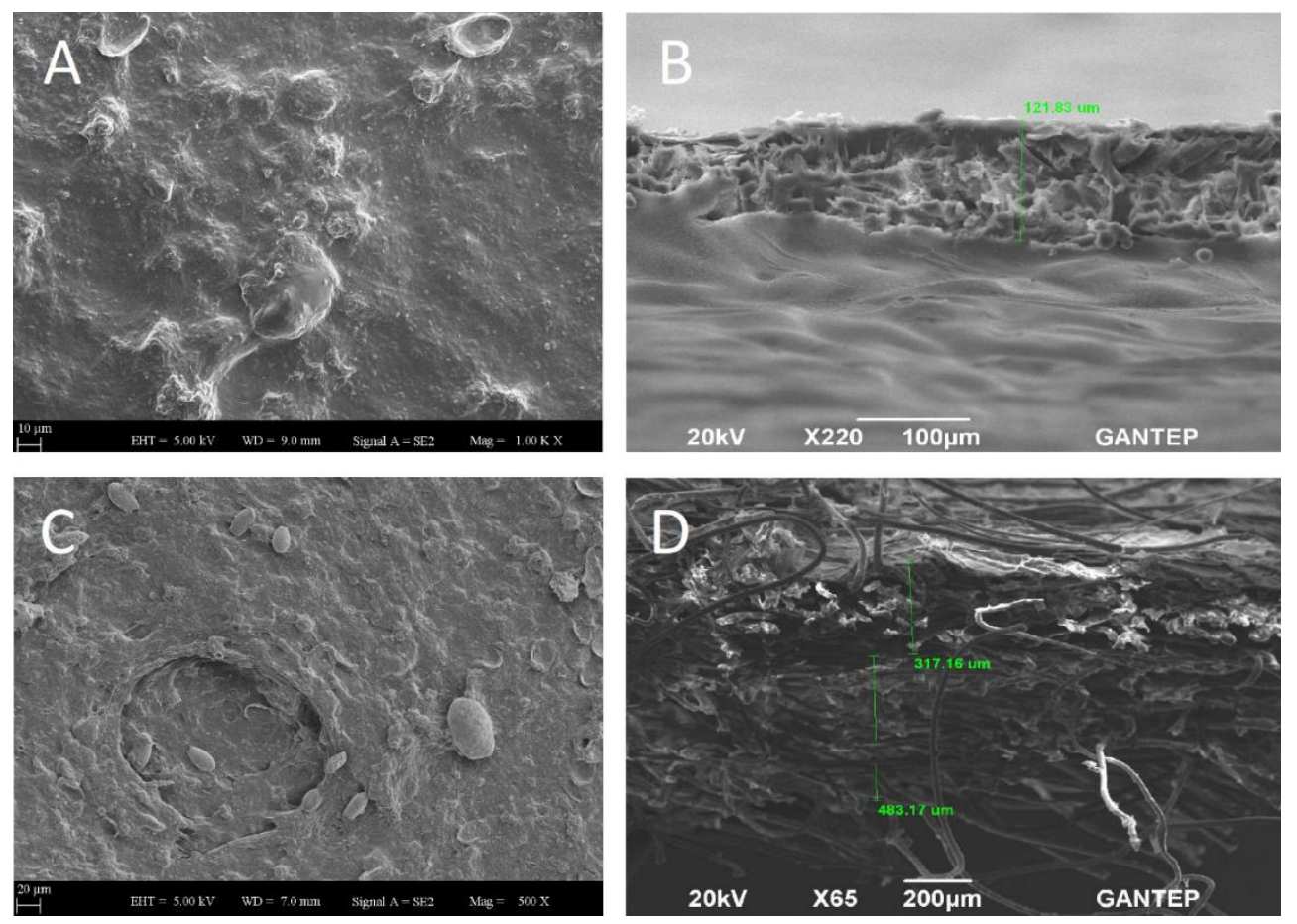

Fig. 8. Surface (A-C) and corss-sectional (B-D) SEM image of the $0.45 \mu \mathrm{m}$ and non-woven dynamic membrane, respectively.

Experimental studies have shown that inorganic elements, such as $\mathrm{Mg}, \mathrm{Al}, \mathrm{Si}, \mathrm{Ca}$ and $\mathrm{Fe}$ cause serious clogging that they can form a transition phase through contaminating layers, precipitated cells, and biopolymers. There was a possibility that these substances may cause clogging in the neglected level when passing over the membrane (Meng et al. 2007; Wang et al. 2008).
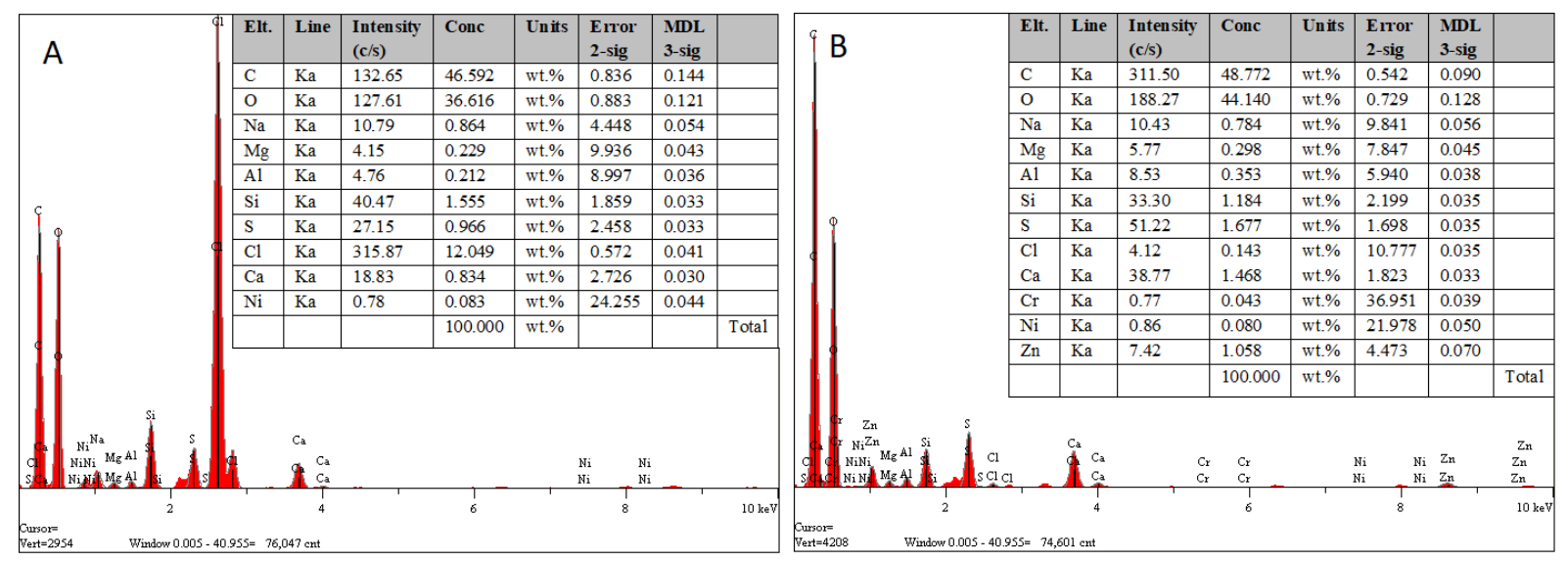

Fig. 9. Concentrations of organic and inorganic constituents on $0.45 \mu \mathrm{m}(\mathrm{A})$ and non-woven (B) dynamic membranes.

\subsection{Microbiological analysis of the sludge}

In the first and the last period of the operation, DGGE analysis was performed to analyze the 16S rDNA fragments of bacteria and the amount of bacteria as a particular population in the reactor (Fig. 10). The microbial population in the sludge changed with the change of air temperature. In the first study, the number of microbial colonies was found as 26 and in the second study this number decreased to 24. In the literature it was reported that the bacterial flora in the reactor changes (due to non/resistance to heat) with the air temperature, room temperature and humidity change (S.-Y. Lee et al. 2004). 


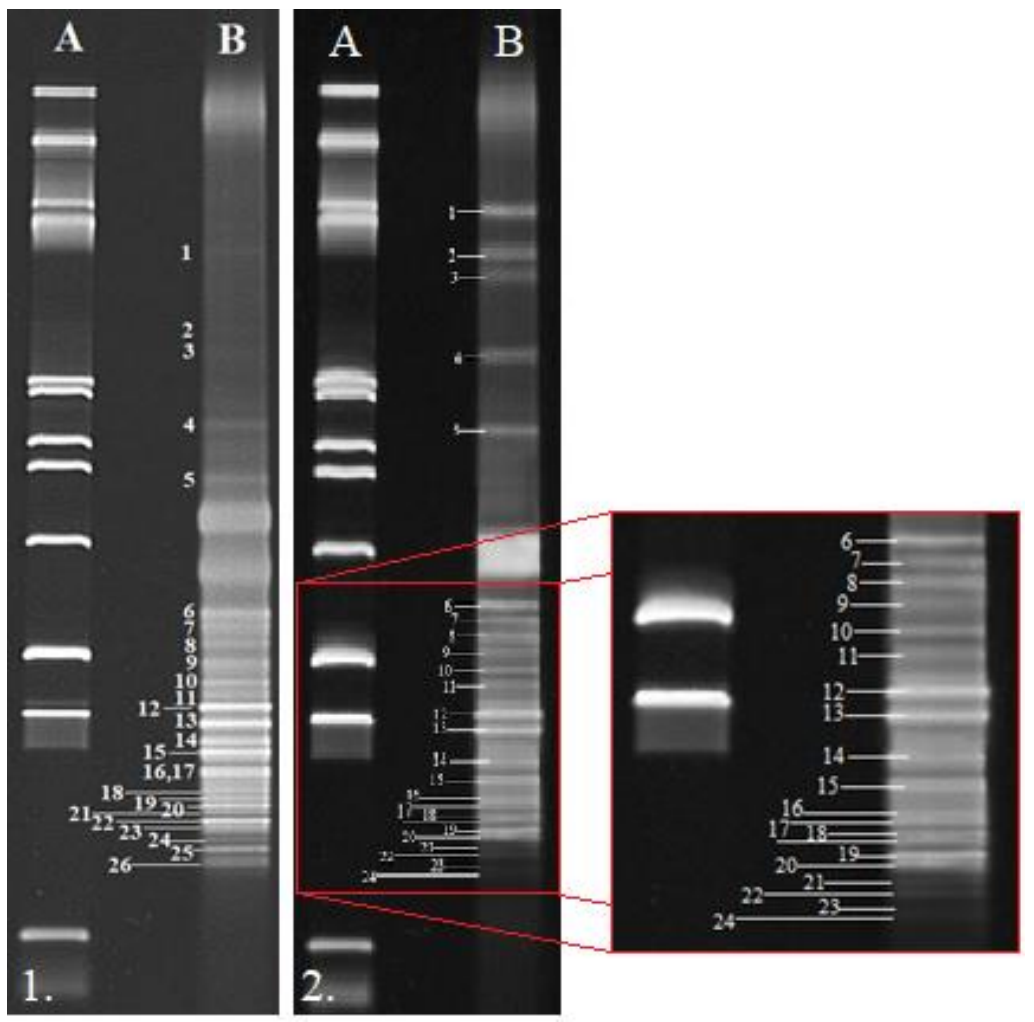

Fig. 10. DGGE results of the first period (1) and last period (2). (Sample A:1 kb marker, sample B: mixed liquor)

\section{Results}

Performance of $0.45 \mu \mathrm{m}$ and non-woven dynamic membrane was investigated in terms of synthetic wastewater treatment in single MBR at room temperature, which changed relatively throughout the time. MBR was operated with infinite SRT and remarkable amount of COD was treated by $0.45 \mu \mathrm{m}$ and non-woven dynamic membrane around $97 \%$ and $86 \%$, respectively. Sludge concentration increased in each period, considering MLSS, SMP, EPS, SRF, SF, CST and Turbidity results. MBR was efficiently operated at 10 LMH for each membrane type and relatively sustainable at $20 \mathrm{LMH}$ flux. Due to the dynamic membrane pore size $(\sim 250 \mu \mathrm{m})$, it was accumulated more biomass than the $0.45 \mu \mathrm{m}$ membrane. Offline chemical cleaning not only eliminated almost complete irreversible fouling but also reduced the resistance (due to pressure) that were close to those of new membranes. In fact, at modest fluxes (between 10-15 LMH), it was also possible to operate without chemical cleaning. When the price performance parity was evaluated, it was seen that dynamic membrane performance is fair enough to employ.

\section{References}

An, Y., Wang, Z., Wu, Z., Yang, D., \& Zhou, Q. 2009 Characterization of Membrane Foulants in an Anaerobic Non-Woven Fabric Membrane Bioreactor for Municipal Wastewater Treatmen Chemical Engineering Journal 155(3): 709-15.

Arhin, S. G., Banadda, N., Komakech, A. J., Kabenge, I., \& Wanyama, J. 2016 Membrane Fouling Control in Low Pressure Membranes: A Review on Pretreatment Techniques for Fouling Abatement. Environmental Engineering Research 21(2): 109-20.

Azami, Hamed, Mohammad Hossein Sarrafzadeh, and Mohammad Reza Mehrnia. 2012 Soluble Microbial Products (SMPs) Release in Activated Sludge Systems: A Review. Iranian Journal of Environmental Health Science and Engineering 9(30).

Barker, Duncan J., and David C. Stuckey. 1999 A Review of Soluble Microbial Products (SMP) in Wastewater Treatment Systems. Water Research 33(14): 3063-82.

Chae, So Ryong, Yong Tae Ahn, Seok Tae Kang, and Hang Sik Shin. 2006 Mitigated Membrane Fouling in a Vertical Submerged Membrane Bioreactor (VSMBR). Journal of Membrane Science 280(1-2): 572-81.

Chen, G. W., W. W. Lin, and D. J. Lee. 1996 Capillary Suction Time (CST) as a Measure of Sludge Dewaterability. Water Science and Technology 34(3-4-4 pt 2): 443-48.

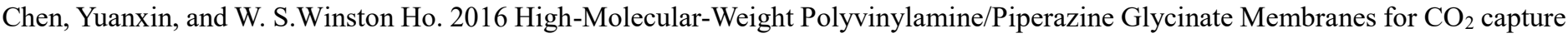
from Flue Gas. Journal of Membrane Science.

Chu, H., Zhang, Y., Zhou, X., Zhao, Y., Dong, B., \& Zhang, H. 2014 Dynamic Membrane Bioreactor for Wastewater Treatment: Operation, Critical Flux, and Dynamic Membrane Structure. Journal of Membrane Science 450: $265-71$.

Chu, Libing, and Shuping Li. 2006 Filtration Capability and Operational Characteristics of Dynamic Membrane Bioreactor for Municipal Wastewater Treatment. Separation and Purification Technology 51(2): 173-79.

Çınar, Ö., Yaşar, S., Kertmen, M., Demiröz, K., Yigit, N. Ö., \& Kitis, M. 2008 Effect of Cycle Time on Biodegradation of Azo Dye in Sequencing Batch Reactor. Process Safety and Environmental Protection 86(6): 455-60.

Croue, J. P., M. F. Benedetti, D. Violleau, and J. A. Leenheer. 2003 Characterization and Copper Binding of Humic and Nonhumic Organic Matter Isolated from the South Platte River: Evidence for the Presence of Nitrogenous Binding Site. Environmental Science 
and Technology 37(2): 328-36.

Drews, A., Vocks, M., Iversen, V., Lesjean, B., \& Kraume, M. 2006 Influence of Unsteady Membrane Bioreactor Operation on EPS Formation and Filtration Resistance. Desalination 192(1-3): 1-9.

Ersahin, Mustafa Evren, Hale Ozgun, Yu Tao, and Jules B. van Lier. 2014 Applicability of Dynamic Membrane Technology in Anaerobic Membrane Bioreactors. Water Research 48(1): 420-29.

Fan, Bin, and Xia Huang. 2002 Characteristics of a Self-Forming Dynamic Membrane Coupled with a Bioreactor for Municipal Wastewater Treatment. Environmental Science \& Technology 36(23): 5245-51. http://pubs.acs.org/doi/abs/10.1021/es025789n.

Fu, Zhimin, Fenglin Yang, Feifei Zhou, and Yuan Xue. 2009 Control of COD/N Ratio for Nutrient Removal in a Modified Membrane Bioreactor (MBR) Treating High Strength Wastewater. Bioresource Technology 100(1): 136-41.

Galil, N I, and L Jacob. 2009 Comparative Characterization of Biosolids from a Membrane Bioreactor and from a Sequencing Batch Reactor. Environmental Engineering Science 26(5): 1001-8.

Germain, Eve, Tom Stephenson, and Pete Pearce. 2005 Biomass Characteristics and Membrane Aeration: Toward a Better Understanding of Membrane Fouling in Submerged Membrane Bioreactors (MBRs). Biotechnology and Bioengineering 90(3): 316-22.

Hernandez Rojas, M. E., R. Van Kaam, S. Schetrite, and Claire Albasi. 2005 Role and Variations of Supernatant Compounds in Submerged Membrane Bioreactor Fouling. Desalination 179(1-3 SPEC. ISS.): 95-107.

Jarusutthirak, Chalor. 2003 Fouling and Flux Decline of Reverse Osmosis (RO), Nanofiltration (NF) and Ultrafiltration (UF) Membranes Associated with Effluent Organic Matter (EFOM) during Wastewater Reclamation/Reuse. PhD thesis, University of Colorado at Boulder, USA.

Jeison, D., and J. B. van Lier. 2006 On-Line Cake-Layer Management by Trans-Membrane Pressure Steady State Assessment in Anaerobic Membrane Bioreactors for Wastewater Treatment. Biochemical Engineering Journal 29(3): $204-9$.

Jeong, Tae Young, Gi Cheol Cha, Ik Keun Yoo, and Dong Jin Kim. 2007 Characteristics of Bio-Fouling in a Submerged MBR. Desalination 207(1-3): 107-13.

Jiang, T., Myngheer, S., De Pauw, D. J., Spanjers, H., Nopens, I., Kennedy, M. D., ... \& Vanrolleghem, P. A. 2008 Modelling the Production and Degradation of Soluble Microbial Products (SMP) in Membrane Bioreactors (MBR). Water Research 42(20): 495564.

Judd, S. 2010. Elsevier The MBR Book: Principles and Applications of Membrane Bioreactors in Water and Wastewater Treatment. London, UK.

Kim, In S., and Namjung Jang. 2006 The Effect of Calcium on the Membrane Biofouling in the Membrane Bioreactor (MBR). Water Research 40(14): 2756-64.

Kimura, K., Y. Hane, and Y. Watanabe. 2005 Effect of Pre-Coagulation on Mitigating Irreversible Fouling during Ultrafiltration of a Surface Water. Water Science and Technology 51(6-7): 93-100.

Kimura, Katsuki, Takuro Naruse, and Yoshimasa Watanabe. 2009 Changes in Characteristics of Soluble Microbial Products in Membrane Bioreactors Associated with Different Solid Retention Times: Relation to Membrane Fouling. Water Research 43(4): 1033-39.

Kiser, M. A., Oppenheimer, J., DeCarolis, J., Hirani, Z. M., \& Rittmann, B. E. 2010 Quantitatively Understanding the Performance of Membrane Bioreactors. Separation Science and Technology 45(7): 1003-13.

Kiso, Y., Muroshige, K., Oguchi, T., Yamada, T., Hhirose, M., Ohara, T., \& Shintani, T. 2010 Effect of Molecular Shape on Rejection of Uncharged Organic Compounds by Nanofiltration Membranes and on Calculated Pore Radii. Journal of Membrane Science 358(1-2): 101-13.

Lee, Sangyoup, Eunsu Lee, Menachem Elimelech, and Seungkwan Hong. 2011 Membrane Characterization by Dynamic Hysteresis: Measurements, Mechanisms, and Implications for Membrane Fouling. Journal of Membrane Science 366(1-2): 17-24.

Lee, Soo-Youn, Hyeon-Guk Kim, Jong Bok Park, and Yong Keun Park. 2004 Denaturing Gradient Gel Electrophoresis Analysis of Bacterial Populations in 5-Stage Biological Nutrient Removal Process with Step Feed System for Wastewater Treatment. Journal of microbiology (Seoul, Korea) 42(1): 1-8.

Liu, Yong Qiang, Benjamin Moy, Yun Hua Kong, and Joo Hwa Tay. 2010 Formation, Physical Characteristics and Microbial Community Structure of Aerobic Granules in a Pilot-Scale Sequencing Batch Reactor for Real Wastewater Treatment." Enzyme and Microbial Technology 46(6): 520-25.

Ma, J., Wang, Z., Xu, Y., Wang, Q., Wu, Z., \& Grasmick, A. 2013 Organic Matter Recovery from Municipal Wastewater by Using Dynamic Membrane Separation Process. Chemical Engineering Journal 219: 190-99.

Meng, F., Chae, S. R., Drews, A., Kraume, M., Shin, H. S., \& Yang, F. 2009 Recent Advances in Membrane Bioreactors (MBRs): Membrane Fouling and Membrane Material. Water Research 43(6): 1489-1512.

Meng, Fangang, Hanmin Zhang, Fenglin Yang, and Lifen Liu. 2007 Characterization of Cake Layer in Submerged Membrane Bioreactor. Environmental Science and Technology 41(11): 4065-70.

Mohammadi, T., M. Kazemimoghadam, and M. Saadabadi. 2003 Modeling of Membrane Fouling and Flux Decline in Reverse Osmosis during Separation of Oil in Water Emulsions. Desalination 157(1-3): 369-75.

Özkaya, Bestami, and Ahmet Demir. 2011 Microbial Community Analysis with PCR DGGE-SEQUENCING Based Molecular Methods in Municipal Solid Waste Management. Sigma Mühendislik ve Fen Bilimleri Dergisi 3: 219-27.

Reid, E., Xingrong Liu, and S. J. Judd. 2006 Effect of High Salinity on Activated Sludge Characteristics and Membrane Permeability in an Immersed Membrane Bioreactor. Journal of Membrane Science 283(1-2): 164-71.

Ren, X., Shon, H. K., Jang, N., Lee, Y. G., Bae, M., Lee, J., ... \& Kim, I. S. 2010 Novel Membrane Bioreactor (MBR) Coupled with a Nonwoven Fabric Filter for Household Wastewater Treatment. Water Research 44(3): 751-60.

Rosenberger, Sandra, and Matthias Kraume. 2003 Filterability of Activated Sludge in Membrane Bioreactors. Desalination 151(2): 
195-200.

Sun, Yanmei, Yaoyao Fang, Peng Liang, and Xia Huang. 2016 Effects of Online Chemical Cleaning on Removing Biofouling and Resilient Microbes in a Pilot Membrane Bioreactor. International Biodeterioration and Biodegradation 112: 119-27.

Trussell, R. Shane, Rion P. Merlo, Slawomir W. Hermanowicz, and David Jenkins. 2006 The Effect of Organic Loading on Process Performance and Membrane Fouling in a Submerged Membrane Bioreactor Treating Municipal Wastewater. Water Research 40(14): 2675-83.

US APHA 1998. Standard Methods for Examination of Water and Wastewater. American Public Health Association (APHA), Washington DC, USA.

US APHA 2005. Standard Methods for the Examination of Water and Wastewater. American Public Health Association (APHA), Washington DC, USA.

Wang, Z., Wu, Z., Yu, G., Liu, J., \& Zhou, Z. 2006 Relationship between Sludge Characteristics and Membrane Flux Determination in Submerged Membrane Bioreactors. Journal of Membrane Science 284(1-2): 87-94.

Wang, Z., Ma, J., Tang, C. Y., Kimura, K., Wang, Q., \& Han, X. 2014 Membrane Cleaning in Membrane Bioreactors: A Review. Journal of Membrane Science 468: 276-307.

Wang, Zhiwei, Zhichao Wu, Xing Yin, and Lumei Tian. 2008 Membrane Fouling in a Submerged Membrane Bioreactor (MBR) under Sub-Critical Flux Operation: Membrane Foulant and Gel Layer Characterization. Journal of Membrane Science 325(1): $238-44$.

Wu, J., Le-Clech, P., Stuetz, R. M., Fane, A. G., \& Chen, V. 2008 Effects of Relaxation and Backwashing Conditions on Fouling in Membrane Bioreactor. Journal of Membrane Science 324(1-2): 26-32.

Wu, Z., Wang, Z., Zhou, Z., Yu, G., \& Gu, G. 2007 Sludge Rheological and Physiological Characteristics in a Pilot-Scale Submerged Membrane Bioreactor. Desalination 212(1-3): 152-64.

Yu, G. H., Juang, Y. C., Lee, D. J., He, P. J., \& Shao, L. M. 2009 Filterability and Extracellular Polymeric Substances of Aerobic Granules for AGMBR Process. Journal of the Taiwan Institute of Chemical Engineers 40(4): 479-83.

Yurtsever, Adem, Beste Calimlioglu, and Erkan Sahinkaya. 2017 Impact of SRT on the Efficiency and Microbial Community of Sequential Anaerobic and Aerobic Membrane Bioreactors for the Treatment of Textile Industry Wastewater. Chemical Engineering Journal 314: 378-87.

Zhu, Xuefeng, Zhiwei Wang, and Zhichao Wu. 2011 Characterization of Membrane Foulants in a Full-Scale Membrane Bioreactor for Supermarket Wastewater Treatment. Process Biochemistry 46(4): 1001-9. 